\title{
Could petroleum biodegradation be a joint achievement of aerobic and anaerobic microrganisms in deep sea reservoirs?
}

\author{
Georgiana F da Cruz ${ }^{1,4}$, Suzan P de Vasconcellos ${ }^{2}$, Célio FF Angolini ${ }^{1}$, Bruna M Dellagnezze ${ }^{2}$, Isabel NS Garcia ${ }^{2}$,
} Valéria M de Oliveira ${ }^{2}$, Eugenio $V$ dos Santos Neto ${ }^{3}$ and Anita J Marsaioli ${ }^{1 *}$

\begin{abstract}
Several studies suggest that petroleum biodegradation can be achieved by either aerobic or anaerobic microorganisms, depending on oxygen input or other electron acceptors and appropriate nutrients. Evidence from in vitro experiments with samples of petroleum formation water and oils from Pampo Field indicate that petroleum biodegradation is more likely to be a joint achievement of both aerobic and anaerobic bacterial consortium, refining our previous observations of aerobic degradation. The aerobic consortium depleted, in decreasing order, hydrocarbons $>$ hopanes $>$ steranes $>$ tricyclic terpanes while the anaerobic consortium depleted hydrocarbons $>$ steranes $>$ hopanes $>$ tricyclic terpanes. The oxygen content of the mixed consortia was measured from time to time revealing alternating periods of microaerobicity $\left(\mathrm{O}_{2} \sim 0.8 \mathrm{mg} \mathrm{L}^{-1}\right)$ and of aerobicity $\left(\mathrm{O}_{2} \sim 6.0 \mathrm{mg} . \mathrm{L}^{-}\right.$ $\left.{ }^{1}\right)$. In this experiment, the petroleum biodegradation changed from time to time, alternating periods of biodegradation similar to the aerobic process and periods of biodegradation similar to the anaerobic process. The consortia showed preferences for metabolizing hydrocarbons $>$ hopanes $>$ steranes $>$ tricyclic terpanes during a 90-day period, after which this trend changed and steranes were more biodegraded than hopanes. The analysis of aerobic oil degrading microbiota by the 16S rRNA gene clone library detected the presence of Bacillus, Brevibacterium, Mesorhizobium and Achromobacter, and the analysis of the anaerobic oil degrading microbiota using the same technique detected the presence of Bacillus and Acinetobacter (facultative strains). In the mixed consortia Stenotrophomonas, Brevibacterium, Bacillus, Rhizobium, Achromobacter and 5\% uncultured bacteria were detected. This is certainly a new contribution to the study of reservoir biodegradation processes, combining two of the more important accepted hypotheses.
\end{abstract}

Keywords: Petroleum biodegradation, oxic environment, anoxic environment, 165 rRNA gene, petroleum biomarkers.

\section{Introduction}

Much of the petroleum of the Campos Basin has been altered by microbial degradation decreasing the value of the residual oil. This is a major problem for the global economy (Magot et al. 2000,; Cord-Ruwich et al. 1987,; Connan 1984,; Head et al. 2003,). The action of aerobic bacteria (Roling et al. 2003,; Orphan et al. 2000,; Borzenkov et al. 2006,) in petroleum reservoirs is supported by the presence of sufficient oxygen and of nutrient

\footnotetext{
* Correspondence: anita@iqm.unicamp.br

${ }^{1}$ Chemistry Institute, University of Campinas - UNICAMP, POB 6154, 13084-

971 Campinas, SP, Brazil

Full list of author information is available at the end of the article
}

supplies provided by meteoric waters (Connan 1984,; Voordouw et al. 1996). The rapid biodegradation of $n$ alkanes and other biomarkers has been reported with pure aerobic cultures as well as with consortia (da Cruz et al. 2008).

However, biodegradation of crude oils has also been observed in the absence of oxygen and anaerobic heterotrophic microorganisms requiring nitrate, sulfate, iron, manganese or carbon dioxide as electron acceptors (Borzenkov et al. 2006,; Palmer 1993,; Taylor et al. 2001,) are responsible for crude oil biodegradation (Rahman et al. 2002,; Balk 2007, Jones et al. 2008,; Wilkes et al. 2000,). Addtionally, Jones et al. (2008) observed 
sequential removal of hydrocarbons under methanogenic conditions after 686 days.

Most studies utilize either aerobic or anaerobic microbial consortia separately, however the existence of mixed microbiota in oil reservoirs with both aerobic and anaerobic consortia actively participating of the biodegradation process should be considered. In subsurface conditions anaerobic microorganisms could provide microquantities of oxygen to the aerobic microbiota by reducing salts like sulfate, nitrate or perchlorate, e.g. $\mathrm{ClO}_{4}{ }^{-} \rightarrow \mathrm{ClO}_{3}{ }^{-} \rightarrow \mathrm{ClO}_{2}{ }^{-}$ $\rightarrow \mathrm{Cl}^{-}+\mathrm{O}_{2}$ (Coates 1999,; Derek 2000; Xu et al. 2004,). This oxygen might be trapped into biofilms and build micro aerobic environments, stimulating aerobic bacterial growth and an aerobic biodegradation lifecycle under a specific microbial arrangement (Shen 1996,, da Cruz 2010, Figure 1a). Gradual consumption of the oxygen content would generate an anoxic atmosphere and the beginning of an anaerobic lifecycle following a different microbial arrangement (Figure 1b). The aerobic and anaerobic microorganisms might contribute to a stepwise biodegradation in such a way as to survive in the predominant environment (aerobic and anaerobic).

The goal of the present study was to investigate the potential of aerobic bacteria, anaerobic bacteria and mixed consortia obtained from samples of petroleum formation water and oils from Pampo Field (Brazil) to degrade petroleum biomarkers.

\section{Methods}

\section{Geological settings}

Pampo Sul is one of the giant offshore oil fields in Campos Basin, one of the most prolific oil basins in
Brazil, holding about $85 \%$ of total Brazilian oil reserves (before the pre-salt reservoir discovery) and covering an area of about $100,000 \mathrm{~km}^{2}$, mostly offshore to the $3400 \mathrm{~m}$ isobath (Jahnert et al. 1998,). The origin of the Campos Basin is related to the Early Cretaceous break up of the Gondwanaland supercontinent (Rangel et al. 1994,). The hydrocarbon source potential of these source rocks is very high, as indicated by carbon contents that average $2-6 \%$, but having intervals reaching values as high as 9-12\% (Guardado et al. 2000,). The lacustrine saline sediments of the Lagoa Feia Formation (source rock) were interpreted as the source for the typical "Campos oils", including the samples P1 (Coquinas reservoir in Lagoa Feia Formation, classified as not biodegraded) and P2 (Calcarenites reservoir in Macaé formation, classified as biodegraded) (Mello et al. 1988,; Mohriak et al. 1989), see Figure 2. Among the diagnostic features for these oil types are a high hopane/sterane ratio $(\mathrm{H} / \mathrm{S}>5)$, and predominance of $\mathrm{C}_{27}$ steranes. In non-biodegraded oil P1, the bimodal distribution of $n$-alkanes is conspicuous with predominance of the low molar mass fraction $\left(>n C_{15_{-}}\right)$and a pristane/phytane ratio $>1$. More details are given in Table 1.

\section{Microcosms}

The aerobic experiment was carried out following the methodology previously described by da Cruz et al. (2008),. The aerobic biodegradation process was stimulated by adsorbing oil on sterilized sand and by using 2 g wet cells/30 mg P1 oil/40 mL aqueous Zinder medium (Zinder et al. 1984,). The cells were centrifuged from the

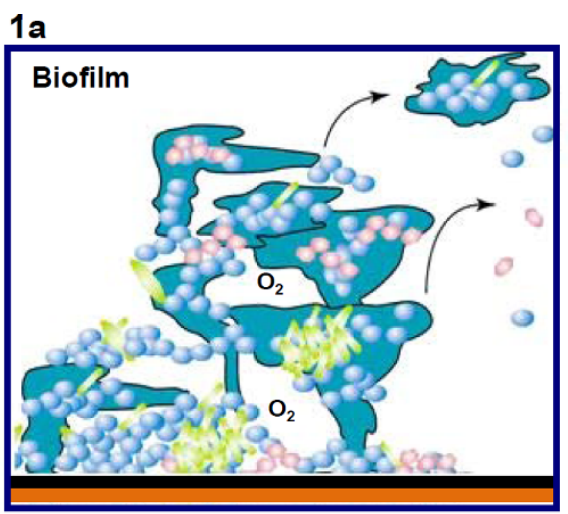

Microorganisms arrangement

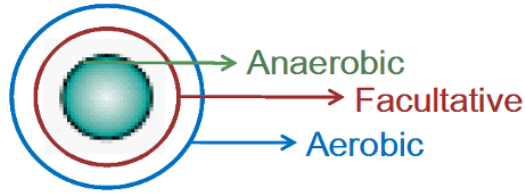

Petroleum
$1 \mathrm{~b}$

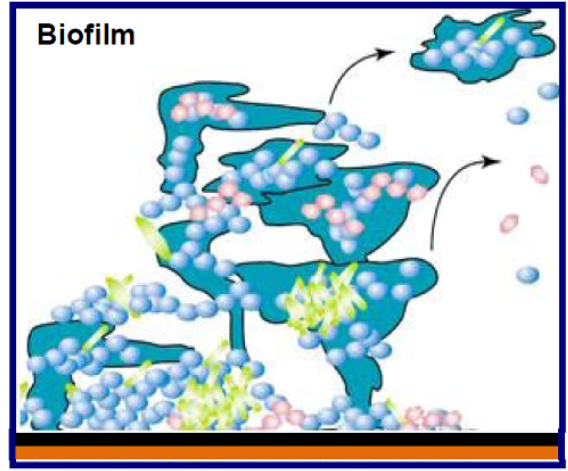

Microorganisms arrangement

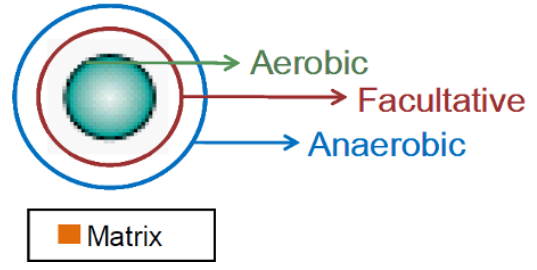

Figure 1 Proposed arrangement of microorganisms in biofilms in an oxic environment (a) and in an anoxic environment (b) 


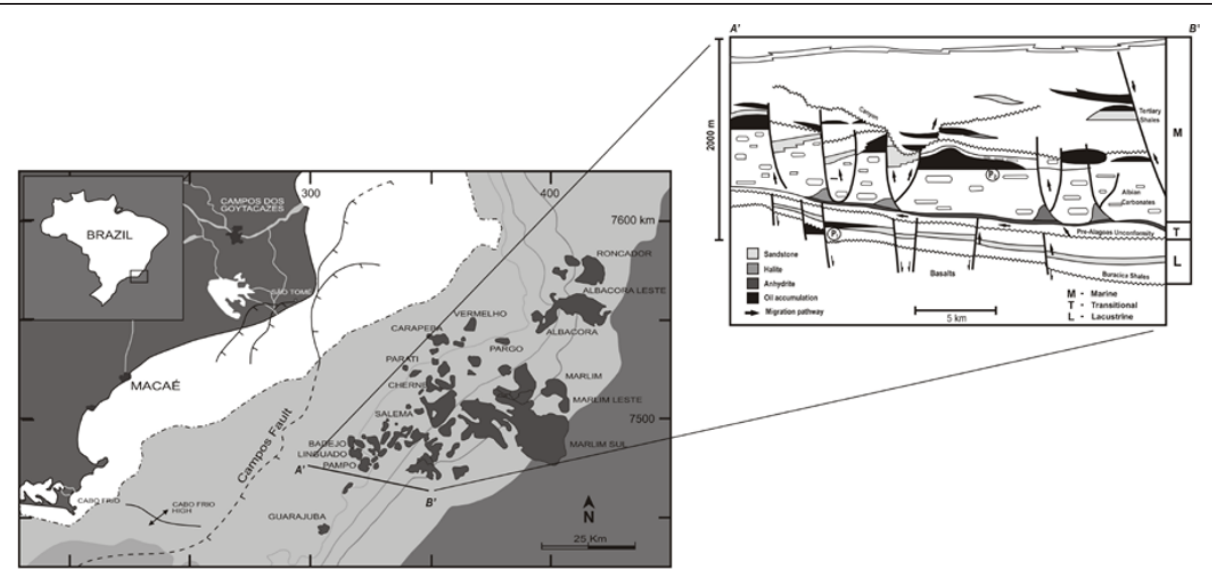

Figure 2 Location of Campos Basin and oil fields. Isolines represent water depth of ocean floor (left). Schematic geological section showing model of oil migration and accumulation in the Campos Basin (right). Marine, transitional and lacustrine refer to the major sedimentary sequences based on the respective depositional environments. P1 and P2 refer to samples described in the text.

enrichment experiment as previously described (da Cruz et al. 2008,). Aerobic consortia was set up in Erlenmeyer flasks incubated in a shaker with temperature and agitation control $\left(30^{\circ} \mathrm{C}\right.$ and $\left.150 \mathrm{rpm}\right)$ during 60 days. Laboratory anaerobic and mixed (aerobic/anaerobic) consortium experiments were set up in $50 \mathrm{~mL}$ glass serum bottles sealed with butyl stoppers and aluminium crimps containins resazurin as redox potential control. The bottles were incubated at $30^{\circ} \mathrm{C}$ during 30 days (with agitation control) and then at $55^{\circ} \mathrm{C}$ for up to 180 days (without stiring). A gas system fitted with an oxygen sensor and with a regulated atmosphere of nitrogen $(80 \%)$ and carbon dioxide (20\%) was used in the preparation and incubation of the anaerobic and mixed microorganism consortium. Each consortium biodegradation experiment was composed of $40 \mathrm{~mL}$ of Zinder nutrient medium (Zinder et al. 1984,) containing sources of organic substrates, nitrogen, phophorus, vitamins and trace minerals, made up in Milli-Q water and $30 \mathrm{mg}$ of non-biodegraded oil (P1 from Pampo Sul Field, Campos Basin, Brazil). For the control experiments the same components were used without crude oil to evaluate the consortia in the absence of oil. Perchlorate was added as an oxygen supply for the mixed consortia and the biodegradation processes were stimulated by adsorbing oil on sterilized sand. The experiments were carried out in duplicate and controls of consortia and Zinder medium were included. Samples were processed following a strict protocol and the anaerobic experiments were run in sealed vials and compared to the control experiments. Volatile losses were taken into account by comparing both experiments. The microbial consortia was slightly dependent on the oil storage period, causing oscillations. A reference aerobic bacterial consortium was discussed by Sette et al (2007).

\section{Hydrocarbon analysis}

The hydrocarbon contents from each sampling were subjected to extraction with dichloromethane every 10 (aerobic consortia) or 30 days (anaerobic and mixed consortium). Hydrocarbon fractions were obtained by silica gel chromatography using hexane as eluent for GC-MS analyses. Gas chromatography was carried out with a Hewlett Packard 5890 instrument connected to a Hewlett Packard 5970-MSD mass detector, fitted with a MDN5S coated capilary column (30 m length, $0.25 \mathrm{~mm}$ internal diammeter, $0.25 \mu \mathrm{m}$ film thickness). The GC conditions were: split injection (10:1), with He as carrier gas at $1 \mathrm{~mL} / \mathrm{min}$. The data were obtained in both full scan and single ion monitoring (SIM) modes, at $70 \mathrm{eV}$ ionization energy. The temperature program was adapted to each biomarker class. The injector temperature was set at $300^{\circ} \mathrm{C}$. The analyses of n-alkanes $(\mathrm{m} / \mathrm{z}$ 71) were performed with the temperature program: $80^{\circ} \mathrm{C}$

Table 1 Geological and geochemical bulk data.

\begin{tabular}{|c|c|c|c|c|c|c|c|c|c|c|}
\hline$\overline{\text { Oil }}$ & $\begin{array}{l}\text { Depth } \\
\text { interval } \\
\text { (m) }\end{array}$ & Age & Temp. $\left({ }^{\circ} \mathrm{C}\right)$ & Reservoir & S (\%) & $\begin{array}{l}\text { Sat. } \\
\text { HCs (\%) }\end{array}$ & $\begin{array}{l}\text { Arom. } \\
\text { HCs (\%) }\end{array}$ & NSOs (\%) & ${ }^{\circ} \mathrm{API}$ & $\overline{\delta^{1} C_{\text {VPDB (\%o) }}}$ \\
\hline$\overline{P 1}$ & $2812-2821$ & $\begin{array}{c}\text { Early } \\
\text { Cretaceus }\end{array}$ & 85 & $\begin{array}{c}\text { Lagoa Feia Formation } \\
\text { (coquinas) }\end{array}$ & 0.18 & 50.70 & 25.35 & 23.94 & 30.7 & -23.61 \\
\hline P2 & $2088-2100$ & $\begin{array}{c}\text { Early } \\
\text { Cretaceus }\end{array}$ & 71 & $\begin{array}{l}\text { Macaé Formation } \\
\text { (calcarenites) }\end{array}$ & 0.65 & 42.55 & 23.68 & 33.77 & 19.7 & -24.52 \\
\hline
\end{tabular}


(hold $2 \mathrm{~min}$ ) to $270^{\circ} \mathrm{C}$ at $4^{\circ} \mathrm{C} / \mathrm{min}$ and at $10^{\circ} \mathrm{C} / \mathrm{min}$ to $300^{\circ} \mathrm{C}$ (hold $25 \mathrm{~min}$ ). For the analyses of hopanes and homohopanes $(m / z 191), 25$-norhopanes $(m / z 177)$ and steranes $(\mathrm{m} / z 217)$ the temperature program was: $70^{\circ} \mathrm{C}$ $\left(2 \mathrm{~min}\right.$ ) to $190^{\circ} \mathrm{C}$ at $30^{\circ} \mathrm{C} / \mathrm{min}$, to $250^{\circ} \mathrm{C}$ at $1.5^{\circ} \mathrm{C} / \mathrm{min}$ and at $2^{\circ} \mathrm{C} / \mathrm{min}$ to $300^{\circ} \mathrm{C}$ (hold $20 \mathrm{~min}$ ). All samples were analyzed in duplicate using $5 \alpha$-cholestan-3-one, $0.02 \mu \mathrm{g} / \mathrm{mL}$, as internal standard for the quantitative analyses of biomarker biodegradation. The instrument response was regularly checked by injecting a mixture of n-alkanes.

Biomarker biodegradation ratios were calculated using peak areas from the $m / z 191$ and $m / z 217$ ion chromatograms. The quantitative analyses were carried out following the methodology previously described by da Cruz et al. (2008).

Gas aliquots were removed every 30 days and the headspace composition was analyzed using gas chromatography-mass spectrometry (GC-MS). The amount of dissolved oxygen (DO) was measured during 60 days each 10 days using a galvanic DO probe from Fisher Scientific (the observed range was $8.2-8.7 \mathrm{mg} / \mathrm{L} \pm 1.5 \%$, temperature $22-24.5^{\circ} \mathrm{C}$ ). The anaerobic assays used resazurin as redox indicator, which remained colorless during the experiment indicating an E' of $<-0.11 \mathrm{~V}$. By using the Nernst equation, this redox potential was calculated to correspond to a theoretical oxygen concentration of $<1 \mathrm{pmol} / \mathrm{L} \mathrm{O}_{2}$ (Zeyer et al. 1986). The oxygen in solution was rapidly measured after opening the flasks at room temperature and atmosphere.

\section{DNA extraction and 16S rRNA gene libraries}

One $16 \mathrm{~S}$ rRNA gene library was constructed for each of the aerobic (Co_Aer), anaerobic (Co_Ana) and mixed (Co_mix) microbial consortium. Samples for DNA extraction were taken at the end of the biodegradation assay and replicates of each microbial consortium were pooled before molecular biology procedures. DNA extraction of the bacterial consortia was carried out using a protocol based on Großkopf et al. (1998), and Neria-Gonzáles et al. (2006), with modifications, as follows: the microbial pellets retrieved from enrichments (20 mL-aliquots) were suspended in $600 \mu \mathrm{L}$ PBS buffer, homogenized by vortex and adding lisozyme to a final concentration of $17 \mathrm{mg} / \mathrm{mL}$. After incubation at $37^{\circ} \mathrm{C}$ for $1 \mathrm{~h}$, proteinase $\mathrm{K}$ and SDS were added (final concentration of $0.7 \mathrm{mg} / \mathrm{mL}$ and $2 \%$, respectively) and the solution was incubated at $60^{\circ} \mathrm{C}$ for $30 \mathrm{~min}$. The tubes were subjected to 3 freeze-thaw cycles ( $2 \mathrm{~min}$ in liquid nitrogen followed by $2 \mathrm{~min}$ at $65^{\circ} \mathrm{C}$ ). The solution was extracted once with an equal volume of saturated phenol ( $\mathrm{pH}$ 8.0) and once with an equal volume of chloroform:isoamylic alcohol (24:1). For DNA precipitation, $10 \% \mathrm{NaCl}$ and 2 volumes of cold ethanol were added to the solution. The pellet was washed once with 70\% ethanol, dried and suspended in Milli-Q water. For $16 \mathrm{~S}$ rRNA gene library construction, amplification was performed from total community DNA by using the bacterial primer set $27 \mathrm{f}$ and $1100 \mathrm{r}$ (Lane 1991). Fifty microliters of the reaction mixtures contained $50 \mathrm{ng}$ of total DNA, $2 \mathrm{U}$ of Taq polymerase (GE Healthcare), $0.2 \mathrm{mmol} / \mathrm{L}^{-1}$ of dNTP mix, and $0.4 \mu \mathrm{mol} / \mathrm{L}^{-1}$ of each primer, in $1 \times$ Taq buffer. PCR amplifications were done using 10 cycles of $1 \mathrm{~min}$ at $94^{\circ} \mathrm{C}, 30 \mathrm{~s}$ at $60^{\circ} \mathrm{C}$, decreasing $0.5^{\circ} \mathrm{C}$ each cycle, and 3 min at $72^{\circ} \mathrm{C}$, followed by additional 10 cycles of $1 \mathrm{~min}$ at $94^{\circ} \mathrm{C}, 30 \mathrm{~s}$ at $56^{\circ} \mathrm{C}$ and $3 \mathrm{~min}$ at $72^{\circ} \mathrm{C}$. Amplicons were pooled from five reactions ( $\sim 500 \mathrm{ng})$, purified using GFX ${ }^{\mathrm{TM}}$ PCR-DNA and gel band purification kit (GE Healthcare) and cloned using the pGEM-T cloning vector kit, according to the manufacturer's instructions (Promega, Madison, WI). All the insert-containing clones were submitted to amplified ribosomal DNA restriction analysis (ARDRA) by digesting M13 amplicons with the enzymes Hae III, Hha I and $M s p$ I, at $37^{\circ} \mathrm{C}$ for $2 \mathrm{~h} 30$ min. Clones representing distinct ribotypes were selected for DNA sequencing and phylogenetic analysis. The $16 \mathrm{~S}$ rRNA gene sequences were determined by direct amplification of the inserts from overnight grown-clone cultures with M13 forward and reverse primers and sequencing with the DYEnamic ET Dye Terminator Cycle Sequencing Kit for the automated MegaBace 500 system (GE Healthcare), according to the manufacturer's recommendations.

\section{Sequence analysis}

Partial 16S rRNA gene sequences obtained from clones using forward and reverse primers were assembled in a contiguous sequence using the phred/Phrap/CONSED program (Godon et al. 1997,; Ewing et al. 1998,). Identification was achieved by comparing the contiguous 16S rRNA gene sequences with 16S rRNA sequence data from reference and type strains, as well as environmental clones, available at the public databases Genbank and the RDP (Ribosomal Database Project, Wiscosin, USA) by using BLASTn and RDP sequence match routines. Sequences were aligned using the CLUSTAL X program (Thompson et al. 1997,) and analyzed with MEGA software Version 4.0 (Tamura et al. 2007,). The evolutionary distances were derived from the sequence-pair dissimilarities, calculated as implemented in MEGA using the DNA substitution model reported by Kimura (1980),. The phylogenetic reconstruction was done using the neighbour-joining (NJ) algorithm (Saitou and Nei 1987), with bootstrap values calculated from 1000 replicate runs, using the routines included in MEGA software. The nucleotide sequences determined in this study were deposited at the Genbank database under the accession numbers: FJ493061 to FJ493071. 
For diversity analysis of the $16 \mathrm{~S}$ rRNA libraries, Operational Taxonomic Units (OTU) were defined as distinct ARDRA profiles obtained and total richness as the number of observed OTUs. Coverage values were calculated for each $16 \mathrm{~S}$ rRNA library using the formula of Good (1953),. Rarefaction curves based on ARDRA data were performed using the independent sampling algorithm, implemented in the EcoSim program (Gotelli and Entsminger 2003).

\section{Results}

Two oils from similar source rocks and from the same basin but displaying different levels of biodegradation were selected for laboratory biodegradation experiments using aerobic, anaerobic and mixed (aerobic/ anaerobic) conditions: $i$ ) a non-biodegraded oil (P1, level 1-2) (Peters and Moldowan 1993), and ii) a naturally biodegraded oil (P2, level 4) (Peters and Moldowan 1993). These oils were also used to evaluate in vitro and in reservoir biodegradation parameters based on specific biomarker ratios (Figure 3, Table 2 and Table 3)

Oxygen content was measured every 10 days for 60 days, showing low oxygen content in anaerobic experiments $(8-9 \mathrm{mg} / \mathrm{L})$ and oscillating content in experiments with mixed consortia (between $\sim 0.8 \mathrm{mg} . \mathrm{L}^{-1}$ and $\sim 6 \mathrm{mg}$. $\mathrm{L}^{-1}$ ) (Figure 4).

Consortia of microorganisms present in aerobic, anaerobic and mixed consortium biodegradation experiments were assessed by rRNA $16 \mathrm{~S}$. Community analysis of the
Table 2 Biodegradation (\%) for $\boldsymbol{n}$-alkanes and isoprenoids by aerobic, anaerobic and mixed consortium.

\begin{tabular}{|c|c|c|c|}
\hline \multirow[t]{2}{*}{ Hydrocarbon Compound } & \multicolumn{3}{|c|}{ Biodegradation (\%) } \\
\hline & $\begin{array}{c}\text { Aerobic } \\
\text { (60 days) }\end{array}$ & $\begin{array}{l}\text { Anaerobic } \\
\text { (180 days) }\end{array}$ & $\begin{array}{c}\text { Mixed } \\
\text { (180 days) }\end{array}$ \\
\hline$n$-Tridecane & absent & absent & absent \\
\hline n-Tetradecane & $96 \pm 0.9$ & absent & $48 \pm 1.6$ \\
\hline n-Pentadecane & $>99 \pm 1.60$ & $68 \pm 1.5$ & $51 \pm 1.4$ \\
\hline$n$-Hexadecane & $98 \pm 2.4$ & $63 \pm 1.3$ & $33 \pm 1.1$ \\
\hline n-Heptadecane & $>99 \pm 1.1$ & $50 \pm 0.9$ & $50 \pm 0.8$ \\
\hline Pristane & $>99 \pm 0.6$ & $45 \pm 0.5$ & $46 \pm 0.6$ \\
\hline n-Octadecane & $>99 \pm 0.8$ & $54 \pm 2.1$ & $42 \pm 2.8$ \\
\hline Phytane & $98 \pm 2.7$ & $39 \pm 1.2$ & $39 \pm 1.8$ \\
\hline n-Nonadecane & $>99 \pm 1.7$ & $55 \pm 0.6$ & $57 \pm 0.9$ \\
\hline$n$-Eicosane & $>99 \pm 2.0$ & $45 \pm 2.2$ & $42 \pm 1.2$ \\
\hline n-Heneicosane & $>99 \pm 1.2$ & $69 \pm 1.5$ & $62 \pm 1.8$ \\
\hline n-Docosane & $>99 \pm 1.6$ & $49 \pm 0.9$ & $47 \pm 0.7$ \\
\hline$n$-Tricosane & $>99 \pm 2.7$ & $60 \pm 0.8$ & $60 \pm 0.9$ \\
\hline$n$-Tetracosane & $>99 \pm 1.3$ & $65 \pm 1.3$ & $51 \pm 1.5$ \\
\hline n-Pentacosane & $>99 \pm 0.9$ & $60 \pm 1.8$ & $59 \pm 1.6$ \\
\hline$n$-Hexacosane & $>99 \pm 0.8$ & $64 \pm 0.6$ & $44 \pm 0.9$ \\
\hline n-Heptacosane & $>99 \pm 2.8$ & $68 \pm 1.6$ & $64 \pm 1.8$ \\
\hline n-Octacosane & $>99 \pm 2.6$ & $63 \pm 1.0$ & $41 \pm 2.0$ \\
\hline n-Nonacosane & $>99 \pm 0.6$ & $69 \pm 2.0$ & $67 \pm 1.0$ \\
\hline$n$-Triacontane & $>99 \pm 1.5$ & $44 \pm 1.1$ & $42 \pm 1.3$ \\
\hline$n$-Hentriacontane & $>99 \pm 1.2$ & $49 \pm 1.6$ & $59 \pm 1.9$ \\
\hline n-Dotriacontane & $>99 \pm 1.1$ & $50 \pm 1.1$ & $42 \pm 1.8$ \\
\hline
\end{tabular}

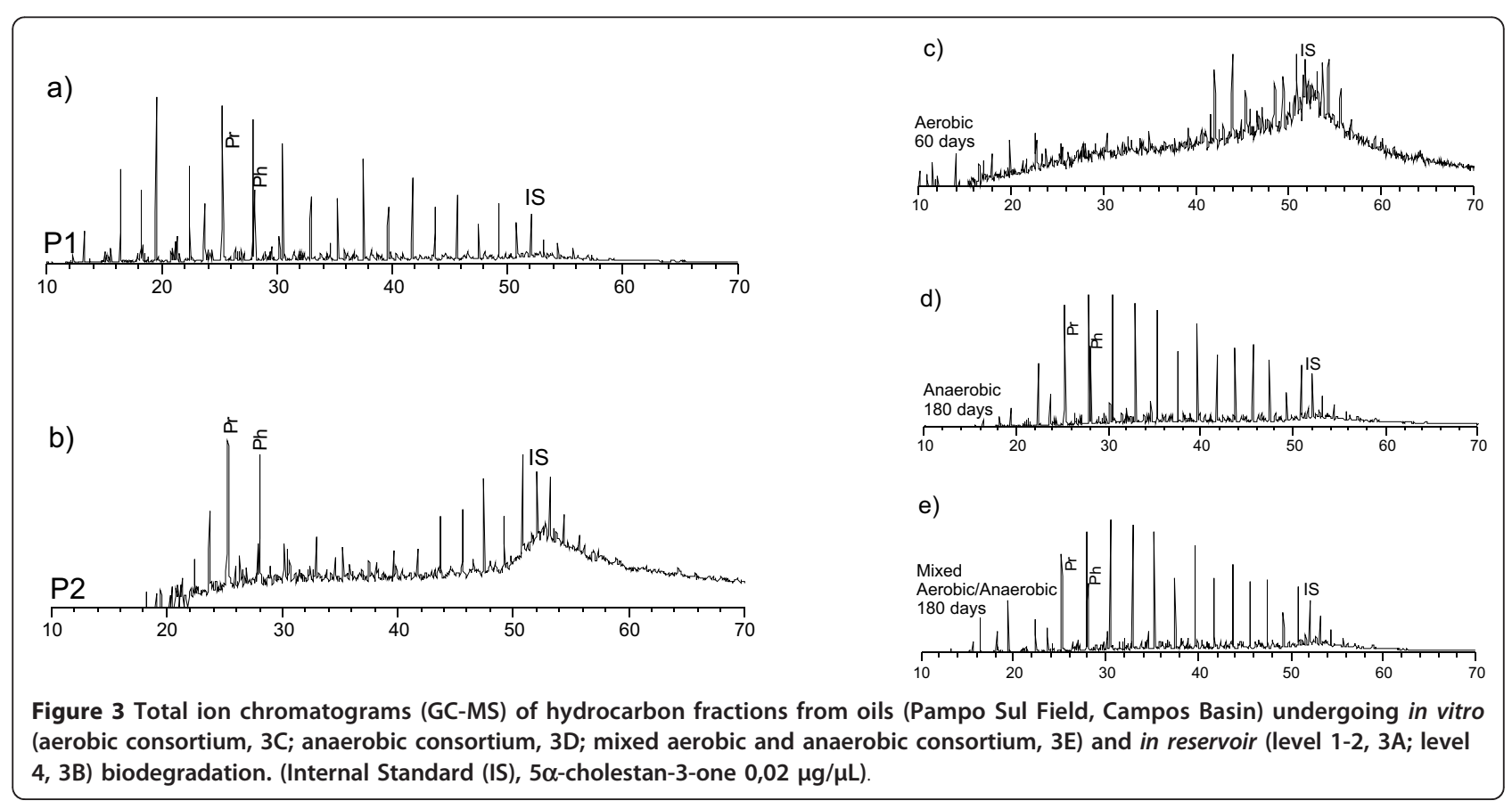


Table 3 Biomarker ratios for different microbial consortium from laboratory degraded oil and from Pampo Sul field (P2).

\begin{tabular}{|c|c|c|c|c|c|c|c|c|c|}
\hline \multirow[t]{2}{*}{ Consortia } & \multirow[t]{2}{*}{ Biomarkers ratios } & \multicolumn{8}{|c|}{ Time (days) } \\
\hline & & Control & 10 & 20 & 30 & 40 & 50 & 60 & P2 \\
\hline \multirow[t]{7}{*}{ Aerobic } & $\mathrm{C}_{28} \mathrm{TT} / \mathrm{C}_{35} \mathrm{H}^{\mathrm{a}}$ & 0.91 & 0.93 & 1.02 & 1.04 & 1.23 & 1.31 & 1.35 & 1.10 \\
\hline & $\mathrm{C}_{29} \mathrm{TT} / \mathrm{C}_{35} \mathrm{H}^{\mathrm{a}}$ & 1.00 & 1.30 & 1.34 & 1.42 & 1.62 & 1.62 & 1.63 & 1.47 \\
\hline & $\mathrm{C}_{35} \mathrm{H} / \mathrm{C}_{30} \mathrm{H}^{b}$ & 0.16 & 0.12 & 0.12 & 0.12 & 0.13 & 0.14 & 0.14 & 0.12 \\
\hline & $\mathrm{Ts} /(\mathrm{Ts}+\mathrm{Tm})^{c}$ & 0.41 & 0.32 & 0.41 & 0.41 & 0.41 & 0.43 & 0.43 & 0.32 \\
\hline & $\mathrm{IH}^{\mathrm{d}}$ & 8.41 & 8.24 & 8.13 & 8.10 & 7.50 & 6.90 & 6.71 & 7.36 \\
\hline & Sterane/Hopane ${ }^{\mathrm{e}}$ & 0.35 & 0.31 & 0.38 & 0.38 & 0.54 & 0.79 & 0.80 & 0.94 \\
\hline & & Control & 30 & 60 & 90 & 120 & 150 & 180 & P2 \\
\hline \multirow[t]{7}{*}{ Anaerobic } & $\mathrm{C}_{28} \mathrm{TT} / \mathrm{C}_{35} \mathrm{H}$ & 0.92 & 1.30 & 0.91 & 1.02 & 0.62 & 0.60 & 0.60 & 1.10 \\
\hline & $\mathrm{C}_{29} \mathrm{TT} / \mathrm{C}_{35} \mathrm{H}$ & 0.94 & 1.41 & 1.22 & 1.23 & 0.81 & 0.73 & 0.61 & 1.47 \\
\hline & $\mathrm{C}_{35} \mathrm{H} / \mathrm{C}_{30} \mathrm{H}$ & 0.15 & 0.12 & 0.14 & 0.14 & 0.19 & 0.19 & 0.18 & 0.12 \\
\hline & $\mathrm{Ts} /(\mathrm{Ts}+\mathrm{Tm})$ & 0.43 & 0.32 & 0.43 & 0.43 & 0.44 & 0.44 & 0.52 & 0.32 \\
\hline & IH & 8.31 & 7.14 & 7.70 & 7.94 & 9.22 & 9.42 & 9.63 & 7.36 \\
\hline & Sterane/Hopane & 0.73 & 0.84 & 0.84 & 0.81 & 0.74 & 0.11 & 0.10 & 0.94 \\
\hline & & Control & 30 & 60 & 90 & 120 & 150 & 180 & P2 \\
\hline \multirow[t]{6}{*}{ Mixed Aerobic/Anaerobic } & $\mathrm{C}_{28} \mathrm{TT} / \mathrm{C}_{35} \mathrm{H}$ & 0.92 & 1.25 & 1.52 & 1.03 & 1.13 & 0.84 & 0.92 & 1.10 \\
\hline & $\mathrm{C}_{29} \mathrm{TT} / \mathrm{C}_{35} \mathrm{H}$ & 0.94 & 1.17 & 1.30 & 1.55 & 1.75 & 1.43 & 1.16 & 1.47 \\
\hline & $\mathrm{C}_{35} \mathrm{H} / \mathrm{C}_{30} \mathrm{H}$ & 0.15 & 0.15 & 0.13 & 0.12 & 0.12 & 0.10 & 0.14 & 0.12 \\
\hline & $\mathrm{Ts} /(\mathrm{Ts}+\mathrm{Tm})$ & 0.29 & 0.24 & 0.27 & 0.27 & 0.28 & 0.28 & 0.28 & 0.32 \\
\hline & IH & 8.31 & 7.19 & 6.78 & 7.47 & 7.65 & 7.86 & 8.57 & 7.36 \\
\hline & Sterane/Hopane & 0.36 & 0.95 & 1.16 & 0.72 & 0.57 & 0.54 & 0.07 & 0.94 \\
\hline
\end{tabular}

${ }^{a}$ Calculated from $\mathrm{m} / \mathrm{z} 191$ mass chromatogram peak areas of the $\mathrm{C}_{28}-\mathrm{C}_{29}$ tricyclic terpanes (TT) $(22 R+22 S) . \mathrm{C}_{35} 17 \alpha .21 \beta(\mathrm{H})$-homohopane $\left(\mathrm{C}_{35} \mathrm{H}\right)(22 R+22 \mathrm{~S})$ and $\mathrm{C}_{30} 17 \alpha .21 \beta(\mathrm{H})$-hopane $\left(\mathrm{C}_{30} \mathrm{H}\right) ;{ }^{\mathrm{b}}$ Calculated from $\mathrm{m} / \mathrm{z} 191$ mass chromatogram peak areas of the $\left[C_{35}(22 R+22 S) /\left(C_{31}-C_{35}\right)(22 R+22 S)\right.$ homohopanes] $\times 100$; ${ }^{c}$ Calculated from $\mathrm{m} / \mathrm{z} 191$ mass chromatogram peak areas of the $C_{27} 17 \alpha(\mathrm{H})$-22.29.30-trisnorhopane $(\mathrm{Tm})$ and $\mathrm{C}_{27} 18 \alpha(\mathrm{H})$-22.29.30-trisnorneohopane $(\mathrm{Ts})$;

${ }^{d}$ Calculated from $\mathrm{m} / \mathrm{z} 191$ mass chromatogram peak areas of the $\left[C_{35}(22 R+22 S) /\left(C_{31}-C_{35}\right)(22 R+22 S)\right.$ homohopanes] $\times 100 ;{ }^{e} C a l c u l a t e d$ from $m / z 217$ mass chromatogram peak areas of the $C_{27}, C_{28}$ and $C_{29} \alpha \alpha \alpha(20 R+22 S)$ and $\alpha \beta \beta(20 R+22 S)$ steranes and from $m / z 191$ of the $C_{29}-C_{33} 17 \alpha(H)$-hopanes $(20 R+22 S)$;

microbial consortia showed that bacterial populations were affiliated to the genera Achromobacter (43\%), Bacillus (32\%), Brevibacterium (10\%) and Mesorhizobium (9\%) in the aerobic consortium, Bacillus (97\%) and Acinetobacter (3\%) in the anaerobic consortium,

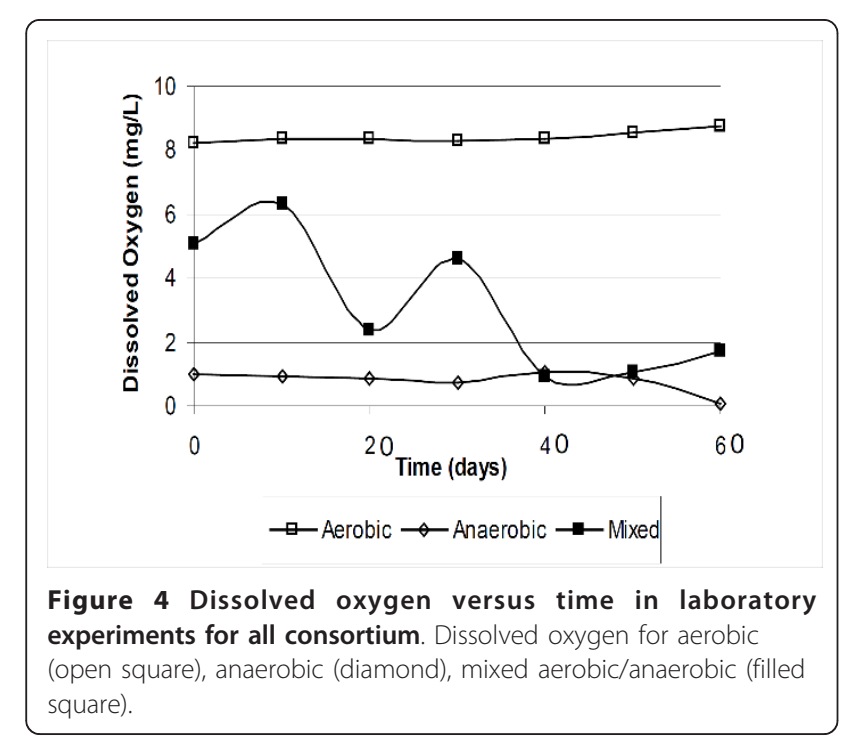

and Stenotrophomonas (49\%), Bacillus (16\%), Rhizobium (11\%), Achromobacter (10\%) and Brevibacterium (10\%) in the mixed consortium (Table 4). High coverage values were found, demonstrating that the bacterial diversity of the consortia was almost fully covered by the clone libraries (Table 4). Rarefaction curves were consistent with the coverage values found and reached saturation for all $16 \mathrm{~S}$ rRNA libraries, specially for Co_Aer and Co_Ana libraries, indicating that the

Table 4 Coverage values and composition of bacterial $16 S$ rRNA gene clone libraries from the aerobic $(A)$, anaerobic (B) and mixed (C) consortium.

\begin{tabular}{cccc}
\hline Microorganism & A & B & C \\
\hline Bacillus sp. & $18 \%$ & $89 \%$ & $14 \%$ \\
Brevibacterium sp. & $18 \%$ & & $14 \%$ \\
Mesorhizobium & $5 \%$ & & \\
Achromobacter sp. & $58 \%$ & & $11 \%$ \\
Acinetobacter & & $11 \%$ & \\
Stenotrophomonas sp. & & & $50 \%$ \\
Rhizobium sp. & & & $6 \%$ \\
Uncultured bacterium & & & $5 \%$ \\
\hline
\end{tabular}




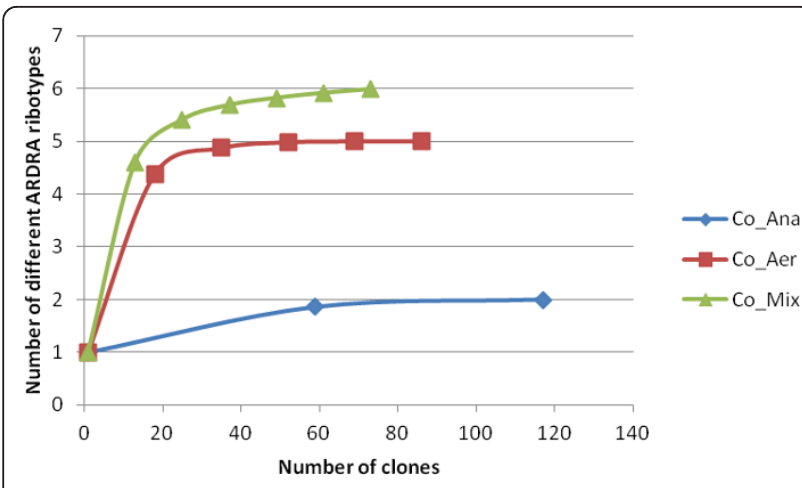

Figure 5 Rarefaction curves of observed OTU richness (number of different ARDRA ribotypes) in bacterial 16S rRNA libraries from consortia samples.

sampling effort was sufficient to reveal all bacterial species present in the consortia under study (Figure 5).

\section{Discussion}

In our assays the aerobic consortium selectively degraded $n$-alkanes and isoprenoids (biodegradation rates of 36 to $99 \%$ in 60 days), with decreasing ratios of pristane $(\mathrm{Pr}) /$ phytane $(\mathrm{Ph})$, increasing ratios of $\operatorname{Pr} / n \mathrm{C}_{17}$ and $\mathrm{Ph} / n \mathrm{C}_{18}$, and an even-to-odd predominance over all the biodegradation process. The anaerobic (micro) consortium showed a slower depletion rate of $n$-alkanes and isoprenoids (39 to $69 \%$ in 180 days) and an odd-to-even predominance. The mixed aerobic/anaerobic consortia alternated $n$-alkane biodegradation preferences (33 to $64 \%$ in 180 days) and the even-to-odd or odd-to-even preferences with lower biodegradation rates than with the pure aerobic consortium (Table 2). It is commonly accepted that odd number n-alkane preference is associated with low oil thermal maturity; however these experimental data reveal that the alkane carbon number predominance can change with the type of biodegradation and should be interpreted with caution.

Headspace monitoring for 270 days (every 10 days) of the anaerobic and mixed consortia detected acetic acid (Heuer et al. 2010, 120 days of biodegradation) and $\mathrm{CO}_{2}$ (270 days of biodegradation) but no methane, indicating the presence of acetogenic bacteria and the absence of methanogenic archaea in the microbiota Zengler et al. (1999) showed that the process of $\mathrm{CH}_{4}$ formation is very slow, taking about 150 days to obtain detectable amounts of $\mathrm{CH}_{4}$.

Biodegradation with the aerobic consortia increased the ratios of tricyclic terpane (TT) $\left[\mathrm{C}_{28}(\mathrm{TT}) / \mathrm{C}_{35}\right.$ $17 \alpha, 21 \beta$-homohopane $\left(\mathrm{C}_{35} \mathrm{H}\right), \mathrm{C}_{29}$ tricyclic terpane (TT)/ $C_{35} 17 \alpha, 21 \beta$-homohopane $\left.\left(C_{35} \mathrm{H}\right)\right]$ with increasing biodegradation time, revealing a preferencial depletion of $(R+S) C_{35}$ hopane (> $82 \%$ depletion) in relation to tricyclic terpane (22 and $17 \%$ depletion of $\mathrm{C}_{28}$ and $\mathrm{C}_{29} \mathrm{TT}$, respectively) (Table 3 ). These assays confirmed the selective biodegradation of $22 R$ homohopane isomers. The anaerobic experiment revealed that these ratios decreased, suggesting a preferential depletion of tricyclic terpane (40 and $38 \%$ depletion for $\mathrm{C}_{28}$ and $\mathrm{C}_{29} \mathrm{TT}$, respectively) relative to $\mathrm{C}_{35}$ hopane (36\% depletion). The aerobic consortia degraded 0 to $22 \% \mathrm{C}_{23}-\mathrm{C}_{31} \mathrm{TT}$, whereas the anaerobic consortia degraded 19 to $40 \%$ of such compounds. This effect reveals that oils with lower tricyclic $/ 17 \alpha$-hopane ratios, usually interpreted as more mature oils, could, in fact, be the consequence of an anaerobic microbiota biodegradation operating at higher temperatures.

The homohopane index decreased for aerobic consortium, showing that $\mathrm{C}_{35}$ is more biodegradable than $\mathrm{C}_{31^{-}}$$\mathrm{C}_{34}$ homohopanes, with preferential biodegradation of the higher molar-mass $22 R$ epimers $\mathrm{C}_{35}>\mathrm{C}_{34}>\mathrm{C}_{33}>$ $\mathrm{C}_{32}>\mathrm{C}_{31}$ extended hopanes. Our data are similar to the results of the laboratory culture experiments made by Goodwin et al. (1983), but opposite to the laboratory studies conducted by Bost et al. (2001). These apparent conflicting results indicate that experiments with different consortia produce different biomarker parameters. Therefore the coherence in biodegradation parameters applied to petroleum analyses for the last 60 years indicate that the microbiota in most reservoirs are consistent. The homohopane index increased during the anaerobic biodegradation and indicates a preferential biodegradation of the lower molar mass homohopane $22 R C_{31}>C_{32}>C_{33}>C_{34}>C_{35}$, suggesting that $C_{35}$ is more resistant to the biodegradation process. The bioresistance of higher-hopane homologs has been reported in different oils (Moldowan and McCaffrey 1995,; Peters and Moldowan 1991).

The experiment with mixed consortia, revealed an oscillating content of oxygen with periods of microaerobicity, at $\sim 0.8 \mathrm{mg} / \mathrm{L}$ and aerobicity at $\sim 6 \mathrm{mg} / \mathrm{L}$ of oxygen. These experiments were performed in closed vessels, therefore the oxygen was generated and consumed by the microbiota in alternated lifecycles (Figure 4). The biodegradation preference for all biomarkers was unusual, with aerobic characteristics (increasing $\mathrm{C}_{28}$ TT from 30 to 90 days, Table 3) alternating with anaerobic ones (decreasing $\mathrm{C}_{28}$ TT from 90 to 120 days, Table 3). The homohopane index decreased in the first 60 days and increased from then on until the assay was completed (180 days), with an unusual homohopane biodegradation preference $\mathrm{C}_{33}>\mathrm{C}_{32}>\mathrm{C}_{31}>\mathrm{C}_{34}>$ $C_{35}$ Munoz et al. (1997) showed $25 \%$ depletion of $C_{35}$ pentakishomohopane and only $3 \%$ depletion of $C_{31}$ homohopanes in soils exposed to an oil spill for eight years. Thus the controversial relative suceptibility of homohopanes to biodegradation, observed in the field and in laboratory experiments (Goodwin et al. 1983,; 
Bost et al. 2001,; Moldowan and McCaffrey 1995,; Peters and Moldowan 1991,; Munoz et al. 1997) might be assigned to different microbiota, aerobic, anerobic or both, when dealing with oils of equal origin and reservoir matrix. Consequently our experiments validate the $\mathrm{C}_{35}$ homohopane index traditionally used to evaluate the oxic or suboxic environment, linking this index to aerobic, anaerobic and mixed biodegradations (Obermajer et al. 2000).

The norhopanes $18 \alpha(\mathrm{H})$-22,29,30-trisnorneohopane (Ts) and $17 \alpha(\mathrm{H})-22,29,30$-trisnorhopane $(\mathrm{Tm})$ remained almost unaltered throughout the experiment, with a small $\mathrm{Ts} / \mathrm{Tm}$ ratio increase, indicating that $\mathrm{Tm}$ is more susceptible to biodegradation in all processes (aerobic, anaerobic and mixed).

During aerobic experiments the steranes (67\% depletion) were less degraded than hopanes (87\% depletion) and an increase of the sterane/hopane ratio was observed. Under anaerobic conditions sterane biodegradation ( $80 \%$ depetion) occured before that of hopane (67\% depletion), decreasing the sterane/hopane ratio (Table 3). Mixed and aerobic consortium preferentially biodegraded steranes relative to hopanes (30 to 90 days) however this relative susceptibility was inverted over the next 60 days (120 to 180 days), which is consistent with anaerobic biodegradation. Sterane preferencial biodegradation was equal under both aerobic and anaerobic consortium, $\alpha \alpha \alpha 20 R>\alpha \beta \beta 20 R+\alpha \beta \beta 20 \mathrm{~S} \geq \alpha \alpha \alpha 20 S>$ $>$ diasteranes, and opposite for mixed consortia, $\alpha \beta \beta$ $20 R+\alpha \beta \beta 20 \mathrm{~S}>\alpha \alpha \alpha 20 R>\alpha \alpha \alpha 20 S>>$ diasteranes with increasing carbon number $\mathrm{C}_{27}>\mathrm{C}_{28}>\mathrm{C}_{29}$ for all experiments. The relative susceptibility of these isomers varies considerably and depends on the microbiota involved, as shown by the present results. Therefore the $20 \mathrm{~S} /(20 \mathrm{~S}+20 \mathrm{R})$ ratio used as a thermal maturation parameter should be used with caution.

To link biodegradation to specific biodegrading microbes the 16S rRNA gene sequences of the all three microbiota were analyzed indicating the most abundant genera in each microbiota and their phylogenetic tree (Table 4, Figure 6). The bacterial genera detected have all been previously described in the literature as hydrocarbon degraders and/or being associated with oil field environments (Bieszkiewicz et al. 1998; Orphan et al. 2000,; Chaillan et al. 2004,; Pineda-Flores et al. 2004,; Nestler et al. 2007). The Achromobacter strains that dominate the aerobic consortium were phylogenetically related to the species $A$. xylosoxidans and $A$.

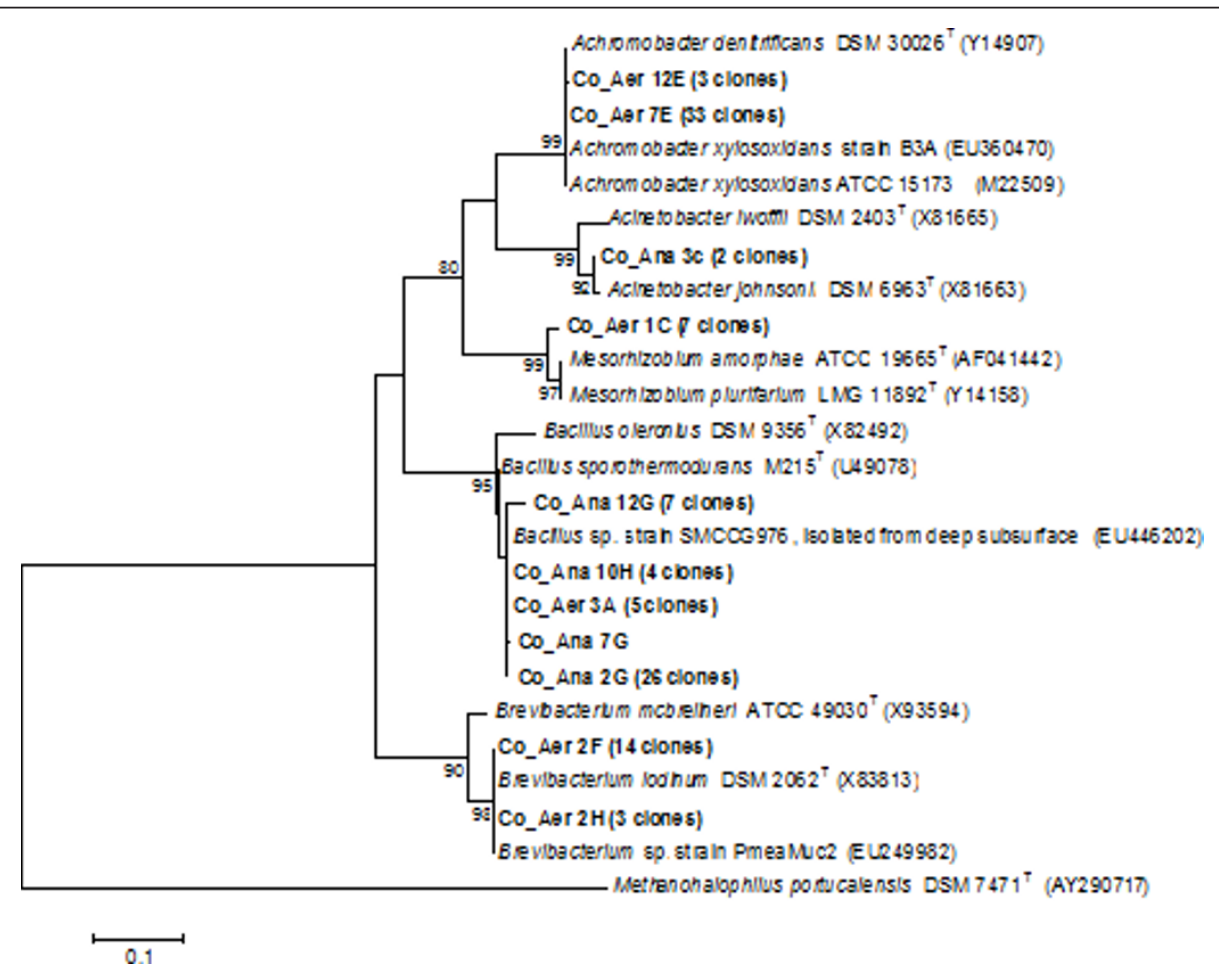

Figure 6 Phylogenetic analysis of partial 16S rRNA gene sequences of clones from aerobic (Co_Aer) and anaerobic (Co-Ana) consortium and related species using the Kimura $2 p$ evolutionary model and the neighbor joining method for tree reconstruction. Bootstrap values (1000 replicate runs, shown as \%) greater than $70 \%$ are listed. Numbers in brackets correspond to additional clones showing $\geq$ 97\% similarity with the clone represented in the branch. GenBank accession numbers are listed after species names. Methanohalophilus portucalensis was used as the outgroup. 
denitrificans (Figure 6). Phylogenetic analysis revealed that Bacillus-related clones from both aerobic and anaerobic consortium were closely related to Bacillus sporothermodurans (Figure 6), which is able to produce highly heat-resistant endospores and has already been found in oil fields (Petterson et al. 1996). Our results corroborate previous literature data on the isolation and biodegradation ability of Bacillus spp. from Brazilian reservoirs (Sette et al. 2007,; Sebastián 1999). The predominance of Bacillus spp. in the anaerobic consortium could be explained by the fact that some species belonging to this genus are facultative anaerobes (Cunha et al. 2006,), capable of shifting their respiration mechanism from aerobic to anaerobic conditions. These bacteria could be responsible for hydrocarbon biodegradation under anaerobic conditions by using sulfate or other salts as electron acceptors, via a dissimilatory sulfate reduction pathway (Clements et al. 2002).

These controlled in vitro experiments (anaerobic, aerobic and both aerobic/microaerobicity conditions) provide a unique ensemble of data that were used in an attempt to explain controversial observations of in reservoir biodegradation and that attested to some biodegradation parameters. The evidence suggests that aerobic biodegradation is mainly responsible for the depletion of the linear hydrocarbons with an even-to-odd carbon preference, although switching to an anaerobic biodegradation, with odd-to-even carbon preference, was observed. The mixed (aerobic and anaerobic consortium) displayed periods of $\mathrm{C}$-even preference and periods of C-odd preference, indicating the existence of alternating aerobic and anaerobic lifecycles. A comparative biodegradation of terpanes, hopanes and steranes under aerobic and anaerobic conditions, Table 3, indicate that some of the controversial biomarker parameters can be easily explained by taking into consideration the microbiota and oxygen content. These results represent an important step in understanding reservoir biodegradation, revealing that anaerobic and aerobic biodegradation can indeed occur without external input of oxygen.

\footnotetext{
Acknowledgements

This work was part of the multidisciplinary project BIOPETRO supported by FINEP and PETROBRAS. G. F. da Cruz was supported by grants from CAPES (Coordenação de Aperfeiçoamento de Pessoal de Nível Superior). S. P. Vasconcellos and C. F. F. Angolini were supported by grants from FAPESP (Fundação de Amparo à Pesquisa do Estado de São Paulo). We thank PETROBRAS for the authorization to publish this work. The authors are grateful to Prof. Carol Collins for revising this text.
}

\section{Author details}

'Chemistry Institute, University of Campinas - UNICAMP, POB 6154, 13084971 Campinas, SP, Brazil ${ }^{2}$ Research Center for Chemistry, Biology and Agriculture (CPQBA), University of Campinas - UNICAMP, POB 6171, 13081970 Campinas, SP, Brazil ${ }^{3}$ Petrobras R\&D Center, Cidade Universitária, Quadra
7, 21949-900 Rio de Janeiro, RJ, Brazil ${ }^{4}$ Engineering and Oil Exploration Laboratory, State University of North Fluminense, 27925-310 Macaé, RJ, Brazil

\section{Authors' contributions}

AJM research team of graduate students GFC, and CFFA carried out the biodegradation experiments, microorganism isolation, hydrocarbon analyses and drafted the manuscript. VMO reasearch team of graduate and post graduate students BMD, INSG and SPV carried out the DNA extraction and $16 S$ rRNA gene libraries. EVSN provided the petroleum samples. EVSN, AJM and $\mathrm{VMO}$ are responsible for supervision and rationale of all experiments. All authors read and approved the final manuscript.

\section{Competing interests}

The authors declare that they have no competing interests.

Received: 20 October 2011 Accepted: 23 December 2011 Published: 23 December 2011

\section{References}

Balk M (2007) Life in the absence of oxygen: alternative electron acceptors for anaerobic microorganisms in a petroleum environment. Turk J Biol 31:59-66

Bieszkiewicz E, Horoch M, Boszczyk-Maleszak H, Mycielski R (1998) An attempt to use selected strains of bacteria adapted to high concentrations of petroleum oil to increase the effective removal of petroleum products in excess activated sludge in laboratory conditions. Acta Microbiol Pol 47:305-312

Borzenkov IA, Milekhina ET, Gotoeva MT, Rozanova EP, Beliaev SS (2006) The properties of hydrocarbon-oxidizing bacteria isolated from the oilfields of Tatarstan, Western Siberia, and Vietnam. Mikrobiologia 75:82-89

Bost FD, Frontera-Suau R, McDonald TJ, Peters KE, Morris PJ (2001) Aerobic biodegradation of hopanes and norhopanes in Venezuelan crude oils. Org Geochem 32:105-114. doi:10.1016/S0146-6380(00)00147-9.

Chaillan F, Flèche A, Bury E, Phantavong Y, Grimont P, Saliot A, Oudot J (2004) Identification and biodegradation potential of tropical aerobic hydrocarbondegrading microorganisms. Res Microbiol 155:587-595. doi:10.1016/j. resmic.2004.04.006

Clements LD, Streips UN, Miller BS (2002) Differential proteomic analysis of Bacillus subtilis nitrate respiration and fermentation in defined medium. Proteomics 2:1724-1734. doi:10.1002/1615-9861(200212)2:123.0.CO;2-S.

Coates JD (1999) Ubiquity and diversity of disimilatory (per)chlorate-reducing bacteria. Appl Environ Microbiol 65:5234-5241

Connan J (1984) Biodegradation of crude oils in reservoirs. In: Brooks J, Welte DH (eds). Advances in Petroleum Geochemistry. Academic Press, London, pp 299-330

Cord-Ruwich R, Kleinitz W, Widdel F (1987) Sulphate-reducing bacteria and their activities in oil production. J Petrol Technol 39:97-106

Cunha CD, Rosado AS, Sebastián GV, Seldin L, Weid I (2006) Oil biodegradation by Bacillus strains isolated from the rock of an oil reservoir located in a deepwater production basin in Brazil. Appl Microbiol Biotechnol 73:949-959. doi:10.1007/s00253-006-0531-2

da Cruz GF, Santos Neto EV, Marsaioli AJ (2008) Petroleum degradation by aerobic microbiota from the Pampo Sul Oil Field, Campos Basin, Brazil. Org Geochem 39:1204-1209. doi:10.1016/j.orggeochem.2008.04.010.

da Cruz GF, Angolini CFF, Santos Neto EV, Loh W, Marsaioli AJ (2010) Exopolymeric Substances (EPS) Produced by Petroleum Microbial Consortia. J Braz Chem Soc 21(8):1517-1523. doi:10.1590/S0103-50532010000800016.

Derek RL, Coates JD (2000) Novel forms of anaerobic respiration of environmental relevance. Curr Opin Microbiol 3:252-256. doi:10.1016/S13695274(00)00085-0.

Ewing B, Hillier L, Wendl M, Green P (1998) Base-calling of automated sequencer traces using phred. I Accuracy assessment Genome Res 8:175-185

Godon JJ, Zumstein E, Dabert P, Habouzit F, Moletta R (1997) Molecular microbial diversity of an anaerobic digestor as determined by small-subunit rDNA sequence analysis. Appl Environ Microbiol 63:2802-2813

Good IJ (1953) The population frequencies of species and the estimation of population parameters. Biometrika 40:237-264

Goodwin NS, Park PJD, Rawlinson T (1983) Crude oil biodegradation. In: Bjoroy M, Albrecht C, Cornford C, et al (ed) Advances in Organic Geochemistry 1981. John Wiley \& Sons, New York pp 650-658

Gotelli NJ, Entsminger GL (2003) EcoSim: Null models software for ecology. Acquired Intelligence Inc. \& Kesey-Bear, Burlington VT 05465 
Großkopf R, Stubner S, Liesack W (1998) Novel Euryarchaeota lineages detected on rice roots and in the anoxic bulk soil of flooded rice microcosms. Appl Environ Microbiol 64:960-969

Guardado LR, Spadini AR, Brandão JSL, Mello MR (2000) Petroleum system of the Campos Basin, Brazil. In: Mello MR, Katz BJ (eds). Petroleum Systems of South Atlantic Margins. American Asssociation of Petroleum Geologists, Memoir 73 (22): 317-324

Head IM, Jones DM, Larter SR (2003) Biological activity in the deep subsurface and the origin of heavy oil. Nature 426:344-352. doi:10.1038/nature02134.

Heuer VB, Krüger M, Elvert M, Hinrichs K-U (2010) Experimental studies on the stable carbon isotope biogeochemistry of acetate in lake sediments. Org Geochem 41(1):22-30. doi:10.1016/j.orggeochem.2009.07.004.

Jahnert R, França A, Trindade LAF, Quintaes C, Santos P, Pessoa J, Bedregal RP (1998) The petroleum system of Campos Basin. BGP; AAPG International Conference \& Exhibition, November 8-11, Rio de Janeiro, Brasil. Extended abstracts volume 600-601

Jones DM, Head IM, Gray ND, Adams JJ, Rowan AK, Aitken CM, Bennett B, Huang H, Brown A, Bowler BFJ, Oldenburg T, Erdmann M, Larter SR (2008) Crude-oil biodegradation via methanogenesis in subsurface petroleum reservoirs. Nat Lett 451:176-181. doi:10.1038/nature06484.

Kimura M (1980) A simple method for estimating evolutionary rate of base substitutions through comparative studies of nucleotide sequences. J Mol Evol 16:111-120. doi:10.1007/BF01731581.

Lane DJ (1991) 16S/23S rRNA sequencing. In: Goodfellow M, Stackebrandt E (eds). Nucleic Acid Techniques in Bacterial Systematics. John Wiley and Sons, Chichester, pp 115-147

Magot M, Ollivier B, Patel BKC (2000) Microbiology of petroleum reservoirs. Antonie van Leeuwenhoek 77:103-116. doi:10.1023/A:1002434330514.

Mello MR, Gaglianone PC, Brassell SC, Maxwell JR (1988) Geochemical and biological marker assessment of depositional environments using Brazilian offshore oils. Marine Petrol Geol 5:205-223. doi:10.1016/0264-8172(88)900025.

Mohriak WU, Mello MR, Karner GD, Dewey JF, Maxwell JR (1989) Structural and stratigraphic evolution of the Campos Basin, Offshore Brazil. In: Extentional Tectonics and Stratigraphy of North Atlantic Margins, American Asssociation of Petroleum Geologists, Memoir 46(38):577-598

Moldowan JM, McCaffrey MA (1995) A novel microbial hydrocarbon degradation pathway revealed by hopane demethylation in a petroleum reservoir. Geochim Cosmochim Acta 59:1891-1894. doi:10.1016/0016-7037(95)00072-8.

Munoz D, Guiliano M, Doumeng P, Jacquot F, Scherrer P, Mille G (1997) Long term evolution of petroleum biomarkers in mangrove soil. Marine Pollut Bull 34:868-874. doi:10.1016/50025-326X(97)00061-1.

Neria-Gonzáles I, Wang ET, Ramírez F, Romero JM, Hernández-Rodríguez C (2006) Characterization of bacterial community associated to biofilms of corroded oil pipelines from southeast of Mexico. Anaerobe 12:122-133. doi:10.1016/j. anaerobe.2006.02.001.

Nestler H, Kiesel B, Kaschabek SR, Mau M, Schlöman M, Balcke GU (2007) Biodegradation of chlorobenzene under hypoxic and mixed hypoxicdenitrifying conditions. Biodegradation 18:755-767. doi:10.1007/s10532-0079104-z.

Obermajer M, Fowler MG, Snowdon LR, Macqueen RW (2000) Compositional variability of crude oils and source kerogen in the Silurian carbonateevaporite sequences of the eastern Michigan Basin, Ontario, Canada. Bull Can Petrol Geol 48:307-322. doi:10.2113/48.4.307.

Orphan VJ, Taylor LT, Hafenbradl D, Delong EF (2000) Culture-dependent and culture-independent characterization of microbial assemblage associated with high temperature petroleum reservoirs. Appl Environ Microbiol 66:700-711. doi:10.1128/AEM.66.2.700-711.2000.

Palmer SE (1993) Effects of biodegradtion and water washing on crude oil composition. Organic Geochemistry Plenum Press, New York pp 511-533

Peters KE, Moldowan JM (1991) Effects of source, thermal maturity, and biodegradation on the distribuition and isomerization of homohopanes in petroleum. Org Geochem 17:47-61. doi:10.1016/0146-6380(91)90039-M.

Peters KE, Moldowan JM (1993) The Biomarker Guide. Interpreting Molecular Fossils in petroleum and Ancient Sediments. Prentice-Hall, Englewood Cliffs, NJ

Petterson B, Lembke F, Hammer P, Stackebrandt E, Priest FG (1996) Bacillus sporothermodurans, new species producing highly resistant endospores. Inter J System Bacteriol 46:759-764. doi:10.1099/00207713-46-3-759.
Pineda-Flores G, Boll-Arguello G, Lira-Galeana C, Mesta-Howard AM (2004) A microbial consortium isolated from a crude oil sample that uses asphaltenes as a carbon and energy source. Biodegradation 15:145-151

Rahman KSM, Thahira-Rahman J, Lakshmanaperumalsamy P, Banat IM (2002) Towards efficient crude oil degradation by a mixed bacterial consortium. Biores Technol 85:257-261. doi:10.1016/50960-8524(02)00119-0.

Rangel HD, Martins FAL, Esteves FR, Feijó FJ (1994) Bacia de Campos. Bol Geociênc Petrobrás 8:203-217

Roling WFM, Head IM, Larter SR (2003) The microbiology of hydrocarbon degradation in subsurface petroleum reservoirs: perspectives and prospects. Res Microbiol 154:321-328. doi:10.1016/S0923-2508(03)00086-X.

Saitou N, Nei M (1987) The neighbor-joining method: a new method for reconstructing phylogenetic trees. Mol Biol Evol 4:406-425

Sebastián GV (1999) Avaliação da população bacteriana presente em um reservatório de petróleo situado em águas profundas brasileiras, com ênfase no isolamento e caracterização de estirpes de Bacillus. Msc Thesis. Universidade Federal do Rio de Janeiro (RJ), Brazil

Sette LD, Simioni KCM, Vasconcellos SP, Dussan LJ, Neto EV, Oliveira VM (2007) Analysis of the composition of bacterial communities in oil reservoirs from a southern offshore Brazilian basin. Antoine van Leewenhoek 91:253-266. doi:10.1007/s10482-006-9115-5.

Shen CF, Guiot SR (1996) Long-term impact of dissolved O2 on the activity of anaerobic granules. Biotechnol Bioeng 49:611-620. doi:10.1002/(SICI)10970290(19960320)49:63.3.CO;2-Z.

Tamura K, Dudley J, Nei M, Kumar S (2007) MEGA4: Molecular evolutionary genetics analysis (MEGA) software, version 4.0. Mol Biol Evol 24:1596-1599. doi:10.1093/molbev/msm092.

Taylor P, Bennett B, Jones M, Larter S (2001) The effect of biodegradation and water washing on the occurrence of alkylphenols in crude oils. Org Geochem 32:341-358. doi:10.1016/50146-6380(00)00176-5.

Thompson JD, Gibson TJ, Plewniak F, Jeanmougin F, Higgins DG (1997) The ClustalX windows interface: flexible strategies for multiple sequence alignment aided by quality analysis tools. Nucleic Acids Res 24:4876-4882

Voordouw G, Armstrong SM, Reimer MF, Fouts B, Telang AJ, Shen Y, Gevertz D (1996) Characterization of 165 rRNA genes from oil field microbial communities indicates the presence of a variety of sulfate-reducing, fermentative, and sulfide-oxidizing bacteria. Appl Environ Microbiol 62:1623-1629

Wilkes H, Boreham C, Harms G, Zengler K, Rabus R (2000) Anaerobic degradation and carbon isotopic fractionation of alkylbenzenes in crude oil by sulphatereducing bacteria. Org Geochem 31:101-115. doi:10.1016/S0146-6380(99) 00147-3.

Xu J, Trimble JJ, Steinberg L, Logan BE (2004) Chlorate and nitrate reduction pathways are separately induced in the perchlorate-respiring bacterium Dechlorosoma sp. KJ and the chlorate-respiring bacterium Pseudomonas sp. PDA. Water Res 38:673-680. doi:10.1016/j.watres.2003.10.017.

Zengler K, Richnow HH, Rosello-Mora R, Michaelis W, Widdel F (1999) Methane formation from long-chain alkanes by anaerobic microorganisms. Nature 401:266-269. doi:10.1038/45777.

Zeyer J, Kuhn EP, Schawarzenbach PR (1986) Rapid microbial mineralization of toluene and 1,3-dimethylbenzene in the absence of molecular oxygen. Appl Environ Micorbiol 944-947

Zinder SH, Cardwell SC, Anguish T, Lee M, Koch M (1984) Methanogenesis in a thermophilic anaerobic digester: Methanotrix sp. as an important aceticlastic methanogen. Appl Environ Microbiol 47:796-807

doi:10.1186/2191-0855-1-47

Cite this article as: da Cruz et al:: Could petroleum biodegradation be a joint achievement of aerobic and anaerobic microrganisms in deep sea reservoirs? AMB Express 2011 1:47. 